\title{
Isoprenaline and quinidine to calm Brugada VF storm
}

\author{
Guy Furniss
}

Cardiology Department, Torbay General Hospital, Torquay, UK

Correspondence to Dr Guy Furniss, guyfurniss@yahoo.co.uk

\section{Summary}

A 3-year-old man with an implanted cardioverter-defibrillator (ICD) for type 2 Brugada syndrome was admitted to coronary care unit with ventricular fibrillation electrical storm and consequent appropriate recurrent ICD shocks. The rhythm did not settle with conventional antiarrhythmics such as $\beta$-blockers and amiodarone. An isoprenaline infusion was set up with immediate stabilisation of rhythm. After a period of monitoring, the infusion was stopped and oral quinidine was started. He has remained free of problems for 1 year. This case-report summarises these novel treatments for electrical storm in Brugada syndrome and the mechanism behind them.

\section{BACKGROUND}

Electrical storms in patients with implanted cardioverterdefibrillator's (ICD) are very distressing for patients and clinicians alike and will be seen increasingly by nonelectrophysiologists, as defibrillators become more common and patients present to non-specialist centres. This patient was given ineffective therapy on admission which may have potentiated the arrhythmia due to a lack of knowledge and experience. The successful treatment of isoprenaline was started on the basis of a case-report. By writing this up further evidence is provided for a very effective treatment that is widely available.

\section{CASE PRESENTATION}

A 31-year-old man was admitted outside of normal working hours to the emergency department of a district general hospital with repeated shocks from his ICD.

Eight months earlier, he had suffered an out of hospital ventricular fibrillation (VF) arrest. Resting ECG and echocardiography were normal and angiography revealed no coronary artery disease. A flecainide provocation test was performed and he was given a diagnosis of type 2 Brugada syndrome. An ICD was inserted. He had no significant other medical or family history.

The 8 months following ICD implantation were uneventful until the day of admission, when he had a shock
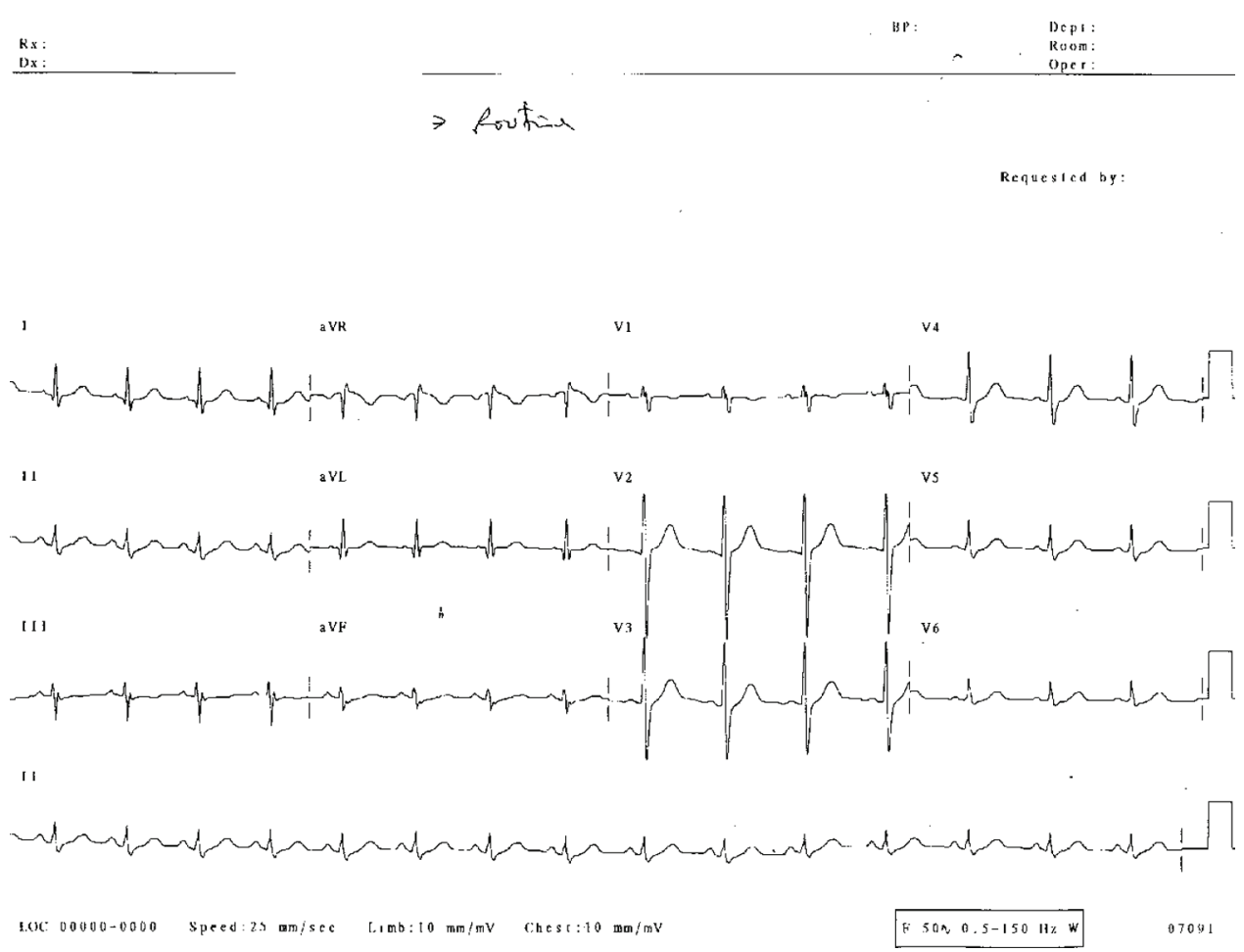

Figure 1 The resting ECG on admission to coronary care. 


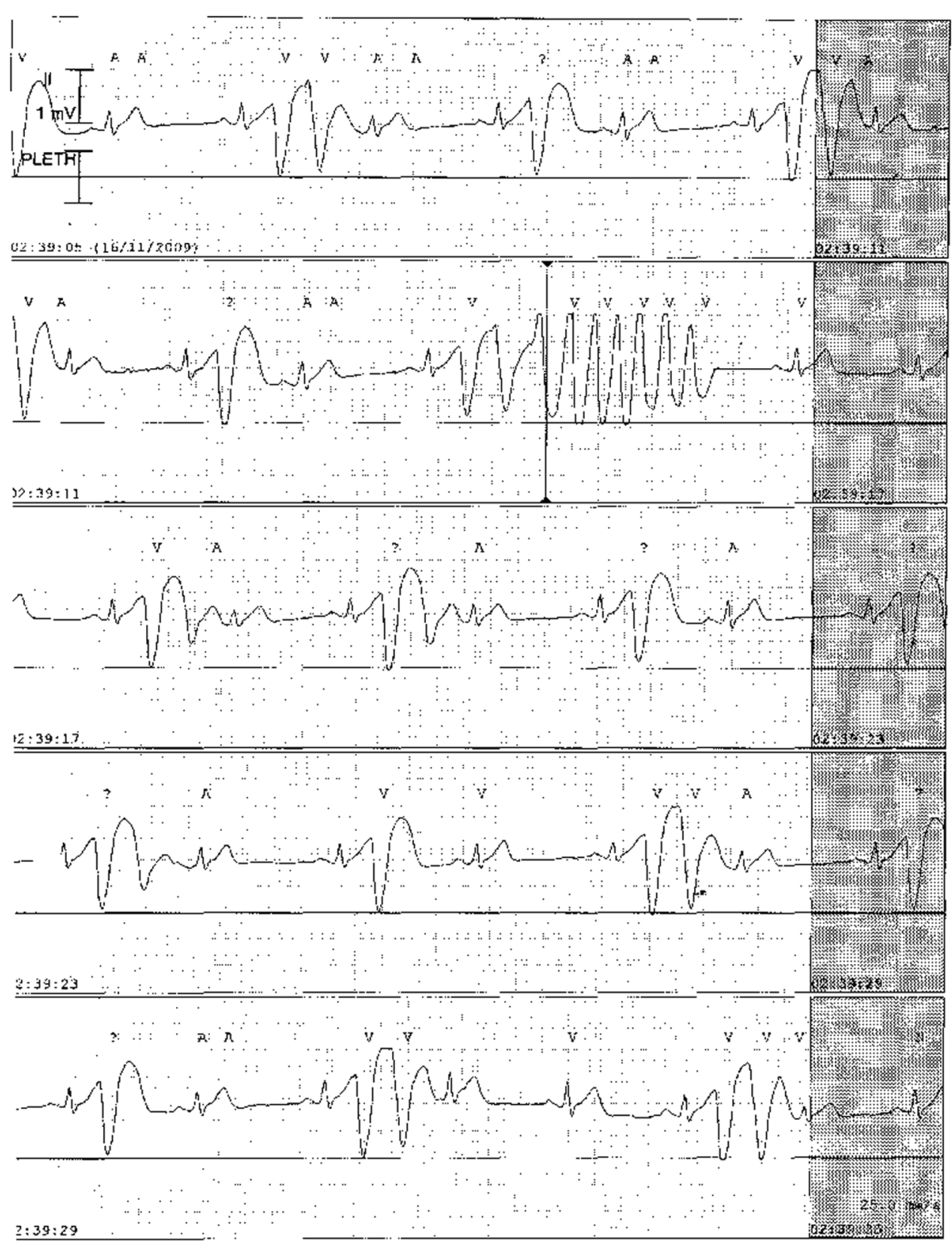

Figure 2 Examples of ventricular ectopy.

from his device at rest. On arrival to the emergency department he had a further shock and was moved to the coronary care unit. His admission ECG and routine bloods were normal (figure 1).

The admitting medical team had discussed with the on-call cardiologist and given $25 \mathrm{mg}$ of oral metoprolol. This failed to prevent ongoing ICD shocks and the patient was commenced on intravenous amiodarone and sedated with morphine and diazepam, following further discussion with the on-call general cardiologist. Despite this he had three further shocks and repeated runs of ventricular bigeminy, ventricular ectopy and polymorphic ventricular tachycardia over the next $4 \mathrm{~h}$ (figures 2 and 3). Intravenous magnesium was added but the gentleman received further shocks and his rhythm did not settle.

Due to the time of day, we were unable to interrogate his ICD, but subsequent analysis showed that, all shocks were appropriate.

\section{TREATMENT}

General anaesthesia was considered as a bridge to the morning, when specialist electrophysiological advice could be sought, but alternative antiarrhythmics were investigated. A literature search revealed that, isoprenaline has been shown to settle electrical storms in Brugada syndrome in the electrophysiology laboratory. ${ }^{1}$ It has also been used in acute settings. ${ }^{2}$ An infusion was set up $(1.5 \mathrm{mcg} / \mathrm{min}$ and titrated up.) There was one further episode of VF as the infusion was commenced but then the rhythm settled. The patient had no further arrhythmias.

After 4 days of observation and monitoring on CCU with no further arrhythmia, we started oral quinidine following specialist advice. The patient was discharged after a further short uneventful period of monitoring. No changes were made to the ICD. 


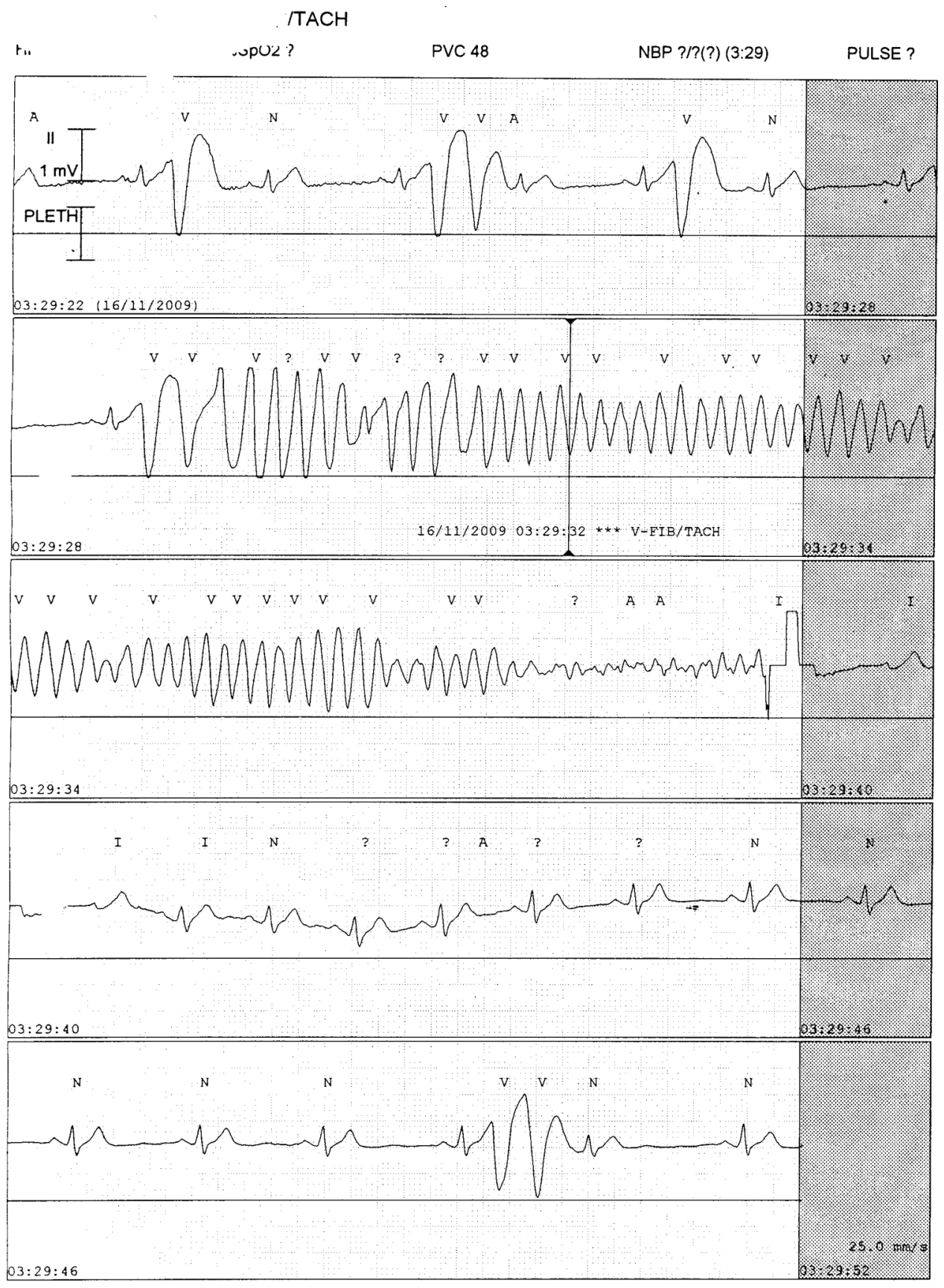

Figure 3 Ventricular ectopy and a salvo of polymorphic ventricular tachycardia.

\section{OUTCOME AND FOLLOW-UP}

The patient has remained on quinidine for 1 year at last follow-up and has remained stable with no further electrical storms. Interrogation of his ICD has not revealed any ventricular arrhythmia or device therapy.

\section{DISCUSSION}

The Brugada syndrome predisposes patients to ventricular fibrillation, due to cardiac sodium channel abnormalities which tend to be of autosomal dominant inheritance. The sodium channel, voltage-gated, type $\mathrm{V}, \alpha$-subunit gene encoding the $\alpha$-subunit of the cardiac sodium gene has been identified in 18-30\% of Brugada syndrome cases (but not in the case discussed).
The defective myocardial sodium channels reduce sodium inflow currents and consequentially reduce the duration of the normal action potential. Phase 0 of the action potential, influx of sodium, is blunted and this results in reduction of calcium inflow and shortening of phase 2 . The cells may therefore fail to conduct the action potential, because dramatically shortened phase 2 recovers excitability quickly. This combination of localised block and short refractory period gives rise to localised re-entry circuits and the potential of arrhythmias in the presence of ventricular premature beats. The effect is more pronounced when there are normal and abnormal sodium channels in the same tissue with heterogeneity of refractory periods. This also occurs between myocardial layers. ${ }^{3} 4$ 


\section{BMJ Case Reports}

Isoprenaline and other sympathomimetic agents (orciprenaline) to terminate electrical storms in Brugada syndrome have been described in catheter lab and case studies. ${ }^{12}$ The mechanism is thought to be due to increasing intracellular calcium, stabilising and restoring the dome in phase 2 of the action potential and reducing the electrical heterogeneity responsible for Brugada syndrome. This stability reduces the susceptibility to VF triggered by premature beats. ${ }^{5}$

Quinidine has been used for over 30 years as prophylaxis in patients with idiopathic ventricular fibrillation ${ }^{6}$ and an $88 \%$ success rate has been shown in preventing VF induction in Brugada patients with inducible VF in one study. ${ }^{7}$ Its action is said to be due to inhibiting transient outward $\left(\mathrm{I}_{\mathrm{to}}\right)$ sodium channels, leading to stabilisation of the action potential. ${ }^{3}$

\section{Learning points}

- VF storm in Brugada syndrome is rare but with increasing use of ICD's and consequent survival, patients are more likely to be seen by the general cardiologist or acute physician.

- Conventional antiarrhythmic agents have shown no benefit. $^{4}$

- This case shows the benefit of isoprenaline in Brugada electrical storms acutely and the use of quinidine for prophylaxis.
Competing interests None.

Patient consent Obtained.

\section{REFERENCES}

1. Maury $\mathbf{P}$, Couderc $P$, Delay $M$, et al. Electrical storm in Brugada syndrome successfully treated using isoprenaline. Europace 2004;6:130-3.

2. Jongman JK, Jepkes-Bruin N, Ramdat Misier AR, et al. Electrical storms in Brugada syndrome successfully treated with isoproterenol infusion and quinidine orally. Neth Heart J 2007;15:151-5.

3. Yan GX, Antzelevitch C. Cellular basis for the Brugada syndrome and other mechanisms of arrhythmogenesis associated with ST-segment elevation. Circulation 1999;100:1660-6.

4. Alings M, Wilde A. "Brugada" syndrome: clinical data and suggested pathophysiological mechanism. Circulation 1999;99:666-73.

5. Kyriazis K, Bahlmann E, van der Schalk H, et al. Electrical storm in Brugada syndrome successfully treated with orciprenaline; effect of low-dose quinidine on the electrocardiogram. Europace 2009;11:665-6.

6. Belhassen B, Shapira I, Shoshani D, et al. Idiopathic ventricular fibrillation: inducibility and beneficial effects of class I antiarrhythmic agents. Circulation 1987;75:809-16.

7. Belhassen B, Glick A, Viskin S. Efficacy of quinidine in high-risk patients with Brugada syndrome. Circulation 2004;110:1731-7.

This pdf has been created automatically from the final edited text and images.

Copyright 2012 BMJ Publishing Group. All rights reserved. For permission to reuse any of this content visit

http://group.bmj.com/group/rights-licensing/permissions.

BMJ Case Report Fellows may re-use this article for personal use and teaching without any further permission.

Please cite this article as follows (you will need to access the article online to obtain the date of publication).

Furniss G. Isoprenaline and quinidine to calm Brugada VF storm. BMJ Case Reports 2012;10.1136/bcr.04.2011.4156, Published XXX

Become a Fellow of BMJ Case Reports today and you can:

- Submit as many cases as you like

- Enjoy fast sympathetic peer review and rapid publication of accepted articles

- Access all the published articles

- Re-use any of the published material for personal use and teaching without further permission

For information on Institutional Fellowships contact consortiasales@bmjgroup.com

Visit casereports.bmj.com for more articles like this and to become a Fellow

Keep up to date with all published cases by signing up for an alert (all we need is your email address) http://casereports.bmj.com/cgi/alerts/etoc 